\title{
Nitrification in Hybrid Reactor with a Recycled Plastic Support Material
}

\author{
Delmira Beatriz Wolff ${ }^{*}$, Juan Carlos Ochoa ${ }^{2}$, Etienne Paul ${ }^{2}$ and Rejane Helena Ribeiro da \\ Costa $^{1}$ \\ ${ }^{1}$ Departamento de Engenharia Sanitária e Ambiental, CTC - Universidade Federal de Santa Catarina; Campus \\ universitário Trindade; 88010-970; delmira@ens.ufsc.br; Florianópolis - SC - Brasil. ${ }^{2}$ LIPE/GPI, Institut National \\ des Sciences Appliquées de Toulouse; Complexe Scientifique de Ranguei; 31077 Toulouse; CEDEX 4 - France
}

\begin{abstract}
This work investigated the nitrification in a hybrid moving bed pilot scale reactor, which used a low density recycled plastic support material for biomass growth. The filling rate was $20 \%$ of its working volume (22L). The feeding and recirculation outflow was $45 \mathrm{~L} /$ day. The reactor operated at a temperature of $16^{\circ} C$, in two phases, according to the sludge retention time (SRT): A phase was 10 days and B phase was 3 days (average values). The applied average volumetric nitrogen and organic loads were $0.16 \mathrm{KgTKN} / \mathrm{m}^{3}$ day and $1 \mathrm{kgCOD} / \mathrm{m}^{3}$.day, respectively. The results showed an average nitrogen removal of $95 \%$ and average COD removal of $89 \%$, in both $A$ and $B$ phases. Nitrogen removal rates were independents of the $S R T$.
\end{abstract}

Key words: Hybrid reactor, nitrification, support, wastewater treatment

\section{INTRODUCTION}

The biological nitrogen removal in effluent treatment conventionally is based on the processes of nitrification and denitrification. Nitrification is a oxidation process $\left(\mathrm{NH}_{4}{ }^{+}\right.$to $\mathrm{NO}_{2}{ }^{-}$and $\left.\mathrm{NO}_{3}\right)$ realised by autotrophics and aerobic organisms, denitrification is an anoxic process $\left(\mathrm{NO}_{3}^{-}\right.$to $\left.\mathrm{N}_{2}\right)$ realised by heterotrophics, facultative anaerobic organisms. In these processes, the conversion efficiency in a single reactor depends on the competition for space and substratum between the heterotrophics and autotrophics organisms (Zhang and Bishop, 1996). Aiming to reduce this competition and to upgrade the simultaneous removal of the organic and nitrogen substance in an single reactor, the hybrid reactors were developed. This process combines the fixed biomass with the suspended biomass. These systems are able to improve the nitrification potential by increasing cellular retention time (or Sludge Retention Time-SRT) independent of sludge discarding (Ochoa et al, 2002). A new technology in hybrid reactors, constituted by moving bed associated with activated sludge was applied with excellent results in the nitrogen removal, in treatment plants around the world. The principle is the growth of a biofilm on a low density support, which moves freely in the biological reactor (Andreottola et al., 1999, Ødegaard et al, 2000). The aim of this work was the nitrification upgrading of aerobic biological treatment plants by means of a hybrid process. The used hybrid process consisted of the combination of activated sludge (suspended biomass) with fixed biomass in an agitated moving bed, which

\footnotetext{
*Author for correspondence
} 
operated at low temperature $\left(16^{\circ} \mathrm{C}\right)$ and low SRT, using recycled plastic particles as support material for the biomass growth.

\section{MATERIALS AND METHODS}

\section{Apparatus}

The experiment was carried out in a pilot-plant reactor, as shown in Fig.1.

The system was constituted by a clear PVC column with working volume of 22 liters (support + sludge) and a settling tank of 2.5 liters, where the sludge was recirculated to the reactor.

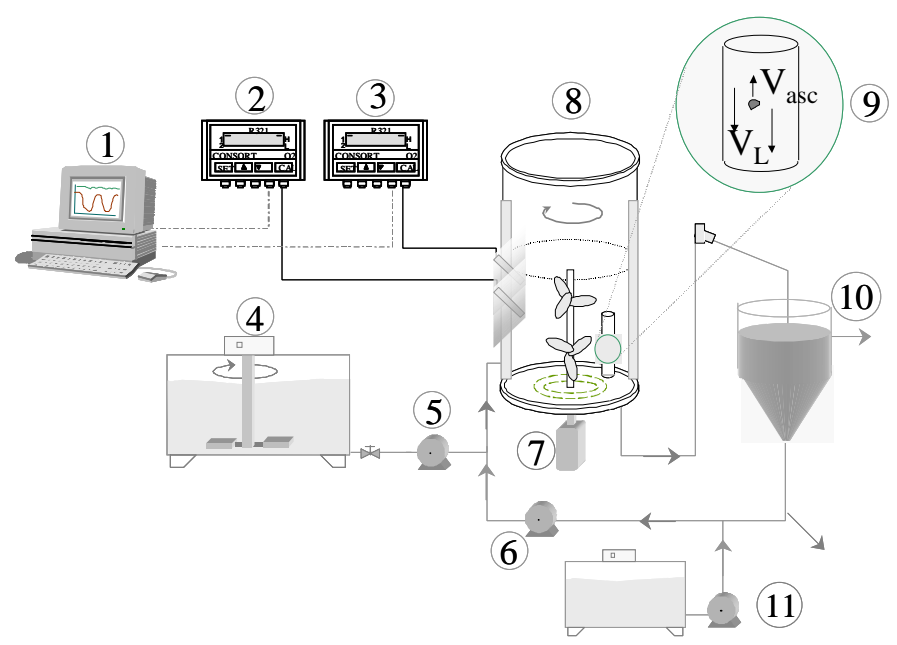

Figure 1 - Schematic diagram of HR system Computer (2) DO and $\mathrm{pH}$ probes (3) Temperature probe (4) Wastewater storage $4^{\circ} \mathrm{C}$ (5) Feed pump (6) Recirculation pump (7) Agitation (8) Biological reactor (9) Support separation device (10) Settler (11) Carbon source

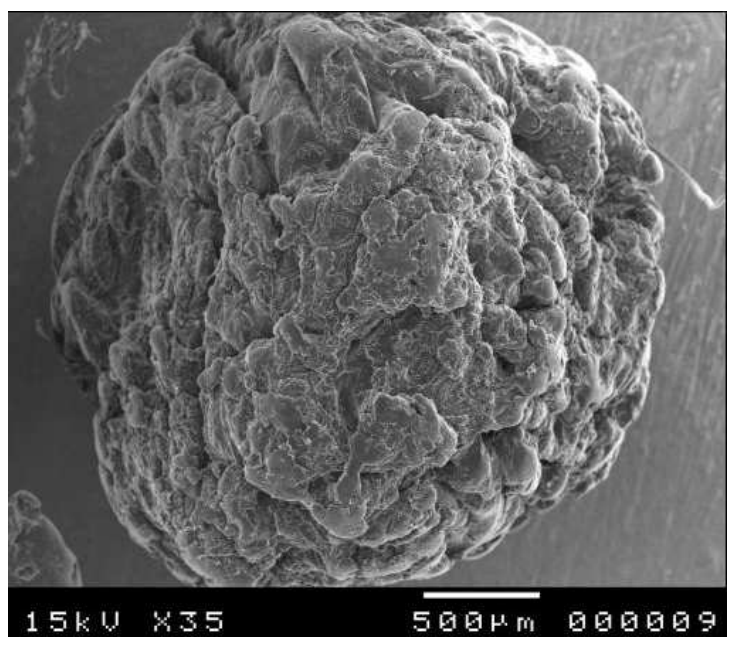

Figure 2 - Support P4 - SEM micrographs electron microscopy view (35X) 
Three peristaltics pumps were used for the feeding system, recycling of sludge and addition of a carbon source, respectively. The support homogenisation in the reactor was realised by mechanical agitation using two marine-helix devices and the supports were holding in the reactor by reducing the reactor outflow velocity as shown in Fig. 1 (9). Aeration was conducted by diffusion of compressed air (ascending aeration). The aeration was sequential, with air supply being cut off each 45 minutes in order to obtain the alternating aerobic and anoxic phases to perform nitrification and denitrification. The temperature was kept $16 \pm 1^{\circ} \mathrm{C}$ by means of a cryogenic unit and monitoring dissolved oxygen and $\mathrm{pH}$ concentration with two CONSORT ${ }^{\circledR}$ units. The system was fed with real urban wastewater from local sewer of Toulouse (France), settled for 15 minutes and stored in a stainless steel tank, shaken and refrigerated to $4^{\circ} \mathrm{C}$.

\section{Material Support}

As material support, a recycled plastic, called P4 was used. This material was wrinkled, had spherical shape, with a average diameter of 2.31 $\mathrm{mm}$, density of $900 \mathrm{~kg} / \mathrm{m}^{3}$ and potential specific surface for the microorganisms growth of the 2597

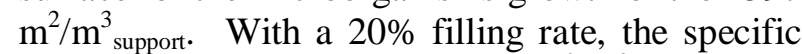
surface in the reactor was $257 \mathrm{~m}^{2} / \mathrm{m}^{3}$ reactor. The material support was inoculated during one week for a activated sludge, and left 55 days in dynamic state for the biofilm development, before starting the daily reactor monitoring. Fig. 2 shows the scanning electron microscopy of a roughness particle.

The surface macroporosities of the support material were appropriate for cell attachment and biofilm formation. This material has been used with good results for Ochoa (1998) in an inversed fluidized bed reactor.

\section{Operational conditions}

The reactor was operated during 227 days in two phases (A and B), defined in function of the SRT ( phase A - average SRT of 10 days and phase B, average SRT of 3 days). The outflows of feeding and recirculation were $45 \mathrm{~L} / \mathrm{day}$. The applied average volumetric loads, in total nitrogen and COD terms was $1 \mathrm{kgCOD} / \mathrm{m}^{3}$.day and $0.16 \mathrm{~kg}$ $\mathrm{TKN} / \mathrm{m}^{3}$.day, calculated in relation to the volume of liquid in the reactor.

\section{Analyses}

Daily analyses were carried out for Chemical Oxygen Demand - COD, total and volatile suspended solids (TSS and VSS), Total Kjeldahl Nitrogen - (TKN) and ammoniacal nitrogen $\left(\mathrm{NH}_{4}\right)$ (Standard Methods, 1998).

Mass balance for nitrogen: The available nitrogen for nitrification $\left(\mathrm{N}_{\text {nitrificable }}\right)$ was calculated by equation 1.

$$
\mathrm{N}_{\text {nitrifiable }}=\mathrm{N}_{\text {in }}-\mathrm{N}_{\text {assimilated }}
$$

where

$$
\mathrm{N}_{\text {in }}=\mathrm{TN} \cdot \mathrm{Q}_{\text {input }}
$$

So, the nitrified nitrogen was obtained using equation 3.

$$
N_{\text {nitrified }}=N_{T K N, \text { in }}-\left(N_{N_{4}, \text { out }}+N_{N_{4}, \text { assimilated }}\right)
$$

\section{RESULTS}

The results obtained in the monitoring period of the reactor, phase $\mathrm{A}$ (SRT $=10$ days) and phase $\mathrm{B}$ (SRT $=3$ days) are presented. The partial nitrogen mass balance, represented for the concentration of available nitrogen for nitrification $\left(\mathrm{N}_{\text {nitrificable }}\right)$, and nitrificated nitrogen fraction, in the phase $\mathrm{A}$ is shown in Fig. 3, and in phase B is shown in Fig. 4. 


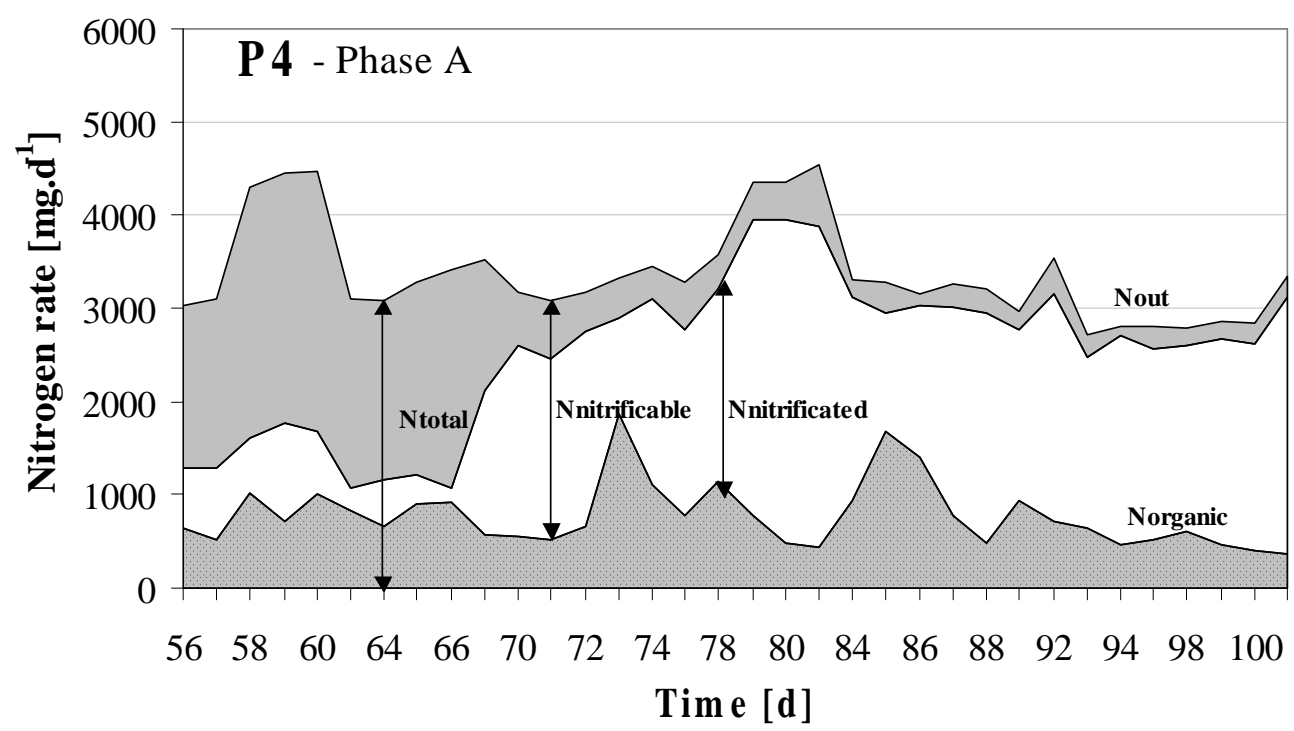

Figure 3 - Mass Balance of nitrogen -nitrification- phase A

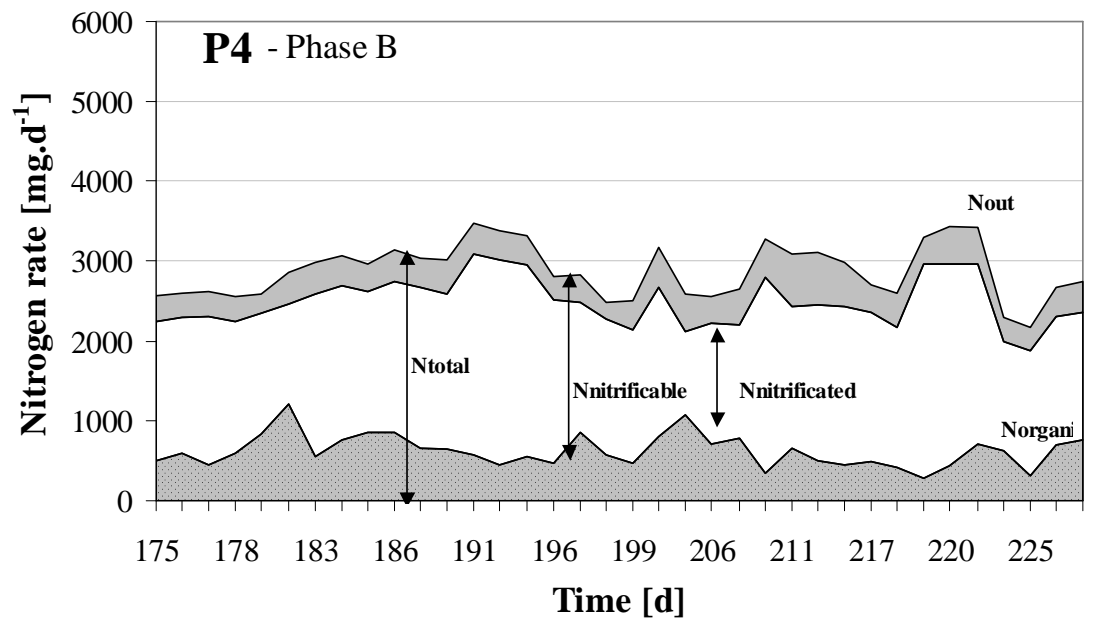

Figure 4 - Mass Balance of nitrogen -nitrification- phase B

Fig. 3 showed that during the first 12 days, the nitrified fraction was low comparative with the nitrificable fraction (total nitrogen removal during this period was 37\%). This occurred because a period of 69 days was necessary to reach the maximal activity of the nitrifying biofilm on the material support. From $70^{\text {th }}$ day, nitrification was stabilised. After this the results showed an average removal of $95 \%$ and maximum removal of $98 \%$ of TKN (average SRT $=10$ days). In consequence, the nitrified fraction increased. With an $\mathrm{SRT}=3$ days, the removal rate stabilised at around $94 \%$ in average and the maximum value was $96 \%$.

Fig. 5 shows the variation of the TKN concentration input and output in the $\mathrm{RH}$ during the monitoring period. It was observed that the HR using the P4 support is robust, because it presented stability in the nitrogen removal with applied load variation. It Total nitrification was 
obtained in reactor operating with a temperature of $16^{\circ} \mathrm{C}$ and low SRT, around 3 days. Wolff et al. (2003) observed that nitrification in hybrid reactors was not influenced by the SRT, because the autotrophic activity was mainly reached to the fixed biomass, where most of the nitrifiers were attached. This showed that this type of reactor is very interesting for nitrogen removal. The roughness of surface of the $\mathrm{P} 4$ support has positive effect on the bacterial growth, the macropores protect the colonised bacteria for the shear stress, and increase the specific surface for the biofilm growth.

Fig. 6 shows the variation of the COD concentration during the monitoring period in phases A and B. Filtered COD showed an more stable performance than total COD and an average removal rate of $89 \%$ in terms of filtered COD was reached.

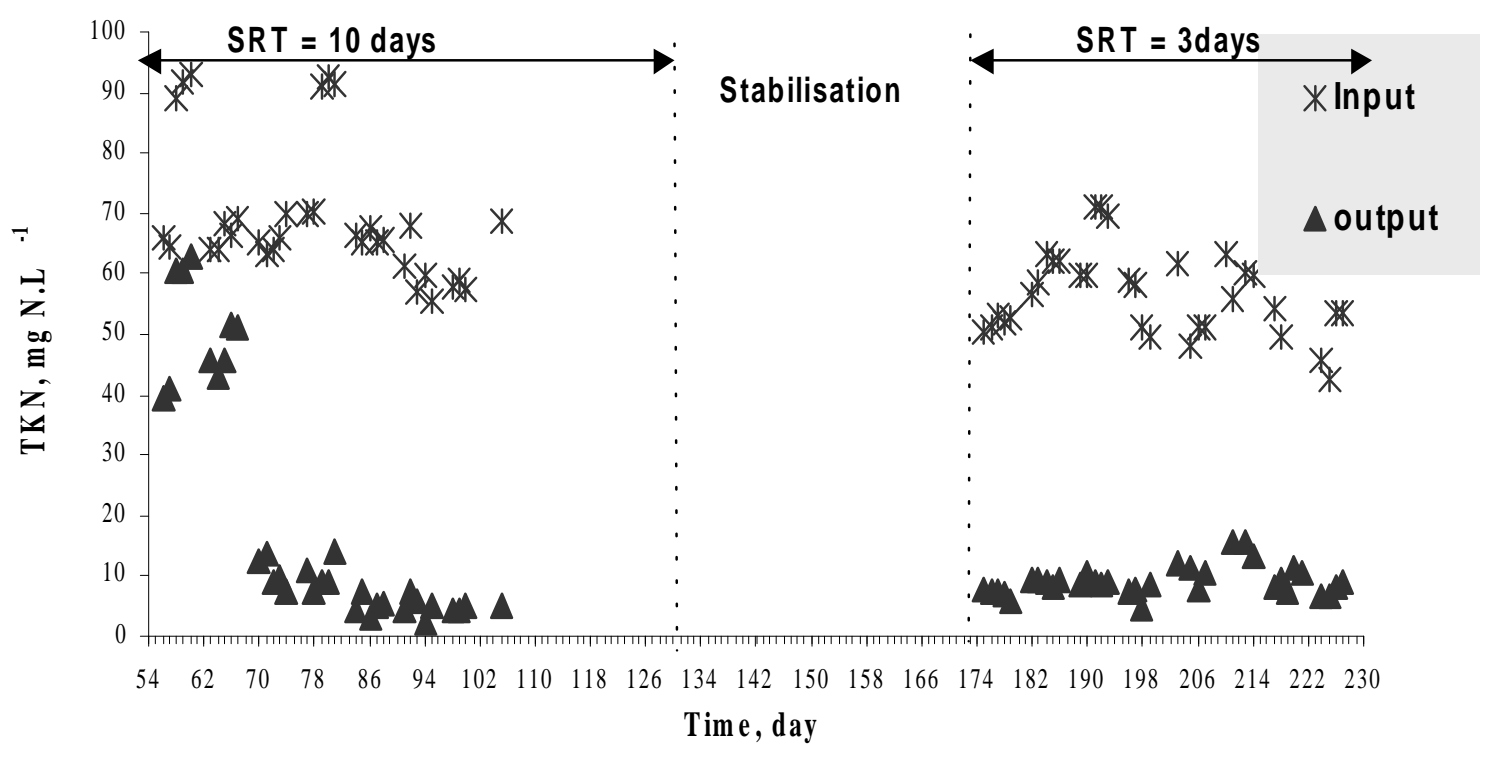

Figure 5. Variation of the TKN concentration input and output- phase A and B

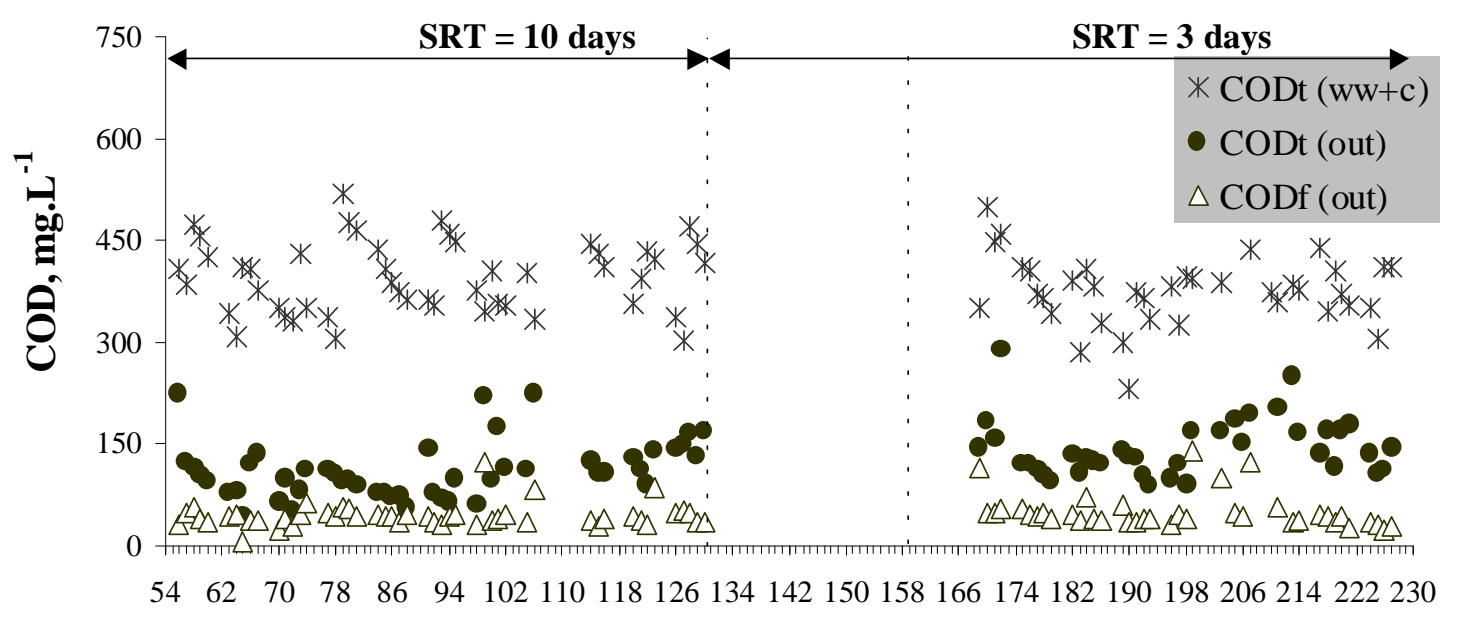

Time, day

Figure 6 - Variation of the COD concentration input and output, phase A and B. 
The fast growing heterotrophic microorganisms can grow in biofilm and in suspension. Under these conditions, the organic matter is mainly oxidised by suspended microorganisms in suspension, while the ammonia compounds are mainly oxidised by the nitrifiers in the biofilm (Oyanedel et al., 2002).

\section{CONCLUSION}

The results showed that the hybrid moving-bed reactors constituted an excellent alternative for biological treatment with nitrification of sanitary sewer. The nitrification was reached with temperature of $16^{\circ} \mathrm{C}$ and very low SRT. The material support in recycled plastic (P4) was efficient in hybrid processes for nitrification, because it allowed the development and activity of biofilm with nitrifiers, which were protecting the hydrodynamic stress in its macropores. Moreover, the P4 presents the following advantages: (1) large specific surface for the bacterial growth; (2) easy to keep in suspension, consequently reduced costs to the aeration and possibility for the use of recycled material. On the other hand, it presents drawbacks as the size of particles (very small) and the difficulty of holding in the hybrid reactor.

\section{ACKNOWLEDGEMENTS}

The authors are grateful to CAPES for financial assistance.

\section{RESUMO}

Este trabalho investiga a nitrificação em um reator-piloto híbrido de leito móvel agitado, que utiliza um plástico reciclado de baixa densidade como material suporte para o crescimento da biomassa. $O$ preenchimento do reator com o suporte era $20 \%$ de seu volume útil (22L). A vazão de alimentação e recirculação era de $45 \mathrm{~L} /$ dia. $\mathrm{O}$ reator foi operado com temperatura de $16^{\circ} \mathrm{C}$, em duas fases, de acordo com a idade do lodo: fase A $=10$ dias e fase $\mathrm{B}=3$ dias (valores médios). As cargas volumétricas médias aplicadas, de nitrogênio e orgânicas foram de $0.16 \mathrm{KgNTK} / \mathrm{m}^{3} \mathrm{dia}$ e de $1 \mathrm{kgDQO} / \mathrm{m}^{3} \mathrm{dia}$, respectivamente. Os resultados mostraram uma redução média de nitrogênio de $95 \%$ e de DQO de $89 \%$, nas duas fases (A e B). A eficiência de remoção de nitrogênio deste reator mostrou ser independente da idade do lodo.

\section{REFERENCES}

Andreottola, G.; Foladori, P.; Ragazzi, M. and Tatano, F. (2000), Experimental comparison between MBBR and activated sludge system for the treatment of municipal wastewater Water Science and Techn., 41 : (4-5), 383-391.

Ochoa, J. C. (1998), Performances épuratoires d'un réacteur type lit fluidisé inversé pour l'élimination $d u$ carbone et de l'azote d'une eau résiduaire urbaine.. Toulouse : DEA/GPS INSA. 68 pp.

Ochoa, J. C.; Colprim, J.; Palacios B.; Paul, E. and Chatellier, P. (2002) Active heterotrophic and autotrophic biomass distribution between fixed and suspended systems in a hybrid biological reactor. Water Science and Techn., 46 (1-2).

Odegaard, H.; Gisvold, B. and Strickland, J. (2000), The influence of carrier size and shape in the moving bed biofilm process. Water Science and Techn., 41 : (4-5), 383-391.

Oyanedel, V.; Garrido, J. M.; Colprim, J.; Lazarova, V. and Mendez, R. (2002) Comparison and modelling of the growth of heterotrophs and nitrifiers in biofilm and hybrid airlift reactors. International Specialised Conference on Biofilm Monitoring, Porto- Portugal, pp. 241-244. [CD ROM].

Standard Methods for the Examination of Water and Wastewater (1998). $20^{\text {th }}$ ed. Am. Pub. Health Assoc./Am. Works Assoc./Water Environ. Fed. Washington DC, USA.

Wolff, D. B.; Ochoa, J. C.; Paul, E. and Costa, R. H. R. (2003). Estudo da biomassa heterotrófica e autotrophic ativa desenvolvida em reatores híbridos no tratamento de esgoto urbano. In: SINAFERM, Florianópolis - SC. Proccedings... Florianópolis. [CDROM].

Zhang T. and Bishop P. (1996) Evaluation of substrate and $\mathrm{pH}$ effects in a nitrifying biofilm. Water Environ. Research, 68 : (7), 1107-1115.

Received: September 29, 2004; Revised: February 25, 2005; Accepted: March 25, 2005. 